Published in final edited form as:

Anal Chem. 2002 August 1; 74(15): 420A-426A.

\title{
The new wave of ion-selective electrodes
}

\author{
Ernö Pretsch \\ Laboratory for Organic Chemistry, ETH Zurich, CH-8093 Zurich, Switzerland, Tel.: +41 44632 2926; \\ Fax: +41 44632 1164; E-mail: pretsche@ethz.ch
}

\begin{abstract}
During the last decade, the capabilities of potentiometric analysis have changed fundamentally in that the lower limit of detection (LOD) of ion-selective electrodes (ISEs) has improved by a factor of up to one million and the discrimination factor of interferences from ions by up to one billion. These spectacular improvements are related to the control of ion fluxes through the ion-selective membrane. Nowadays, ISEs can be used for trace measurements in environmental samples. However, by reducing the volume of the samples, the LOD in terms of the amount of analytes has been reduced to the attomole range. This is promising for bioanalysis using metal nanoparticle labels. Other recent progress includes the excellent fundamental understanding of the working mechanism, the introduction of a novel kind of calibration procedure that reduces the demands on signal stability and reproducibility, and the advent of pulsed amperometric methods.
\end{abstract}

\section{Keywords}

Ion-selective electrode; Lower limit of detection; Selectivity; Trace measurement

\section{Introduction - the status 25 years ago}

Although each novel scientific result has its roots in some earlier findings, it is probably safe to state that different independent achievements in the mid-1960s marked the starting point of modern potentiometry [1]. In 1967, Ross described the first membrane electrode based on a liquid ion exchanger [2] and Bloch and co-workers introduced the first ionophore-based solvent polymeric membrane based on PVC [3], a matrix still widely used today. At about the same time, Stefanac and Simon discovered that antibiotics inducing selective-ion transport through biological membranes also generate a selective potentiometric response in liquid membranes [4]. Finally, this was also the time of birth of host-guest chemistry [5,6], which later played an important role in developing novel selective ionophores.

Subsequently, in the following 15 years, tremendous results were achieved by a number of research groups world-wide [7,8]. Ion-selective electrodes (ISEs) for more than 50 different ions were introduced [8], microelectrodes were pioneered for in vivo measurements [9], and, as the most important development in terms of practical impact and commercial success, potentiometry has become the standard technique in the clinical analysis of ions, including $\mathrm{Na}^{+}, \mathrm{K}^{+}, \mathrm{Ca}^{2+}$, and $\mathrm{Cl}^{-}$. Today, over a billion potentiometric measurements are performed world-wide and more than 10 companies sell blood-gas analyzers with potentiometric detectors for relevant ions using of the order of $100 \mu \mathrm{L}$ blood, serum, or plasma [10].

\footnotetext{
Publisher's Disclaimer: This is a PDF file of an unedited manuscript that has been accepted for publication. As a service to our customers we are providing this early version of the manuscript. The manuscript will undergo copyediting, typesetting, and review of the resulting proof before it is published in its final citable form. Please note that during the production process errors may be discovered which could affect the content, and all legal disclaimers that apply to the journal pertain.
} 
By the early 1990s, potentiometry seemed to be at a standstill and a number of scientists contributing to it turned their attention to other different areas because no major developments seemed to be possible any more. In retrospect, it is clear that several puzzles and inconsistencies had persisted and their more thorough investigation has become the basis of spectacular developments during the last 25 years.

\section{Fundamental understanding}

Ion-selective membranes are among the best studied and understood analytical devices. Much of the current knowledge has been collected during the past decades. Although the theoretical background of potentiometry was a topic of intensive studies from the beginning [11-13], a unanimous perception concerning important issues, such as the role of membrane-internal processes or the response function of ISEs in the presence of ions with different charges, had not been achieved by the early 1990s. Then, numerous experiments were performed with a view to understanding the response mechanism and corroborating the potential-determining process [14]. Today, it is widely accepted that in practically all relevant cases, even in the presence of ion fluxes (see below), changes in the phase-boundary potential $[12,15]$ adequately account for the potentiometric response at steady state. Confusions with regard to the definition and the correct measurement of selectivity coefficients have been resolved [16]. Today, the quantitative description of the potentiometric response of an ISE in the presence of any mixture of mono-, di-, and tri-valent ions is available $[15,17,18]$. It is a strong feature of potentiometry that, once the selectivity coefficients of the relevant ions are known, the response to any mixture of them is fully predictable.

The potentiometric selectivity coefficients are directly related to thermodynamic equilibria in the membrane and at the membrane/sample interface. It is therefore important that various potentiometric [19-22] and optical methods [23] are now available for determining the complex formation constants in the membrane. Such measurements are not only relevant for optimizing the sensors but also for obtaining fundamental parameters in host-guest chemistry [24].

In the early days, no ion exchanger was incorporated in the membrane and, as it turned out later, the potentiometric response relied on ionic impurities of the different components. By now, the kind [25] and the concentration [26,27] of such impurities have been studied well. With electrically charged ionophores, the required charge of the added ion exchanger can be predicted [28,29] and used for elucidating the carrier mechanism [30]. Even apparently nonNernstian ISE responses are theoretically well understood [31,32].

Not only thermodynamic parameters but also time-dependent processes in the bulk and at the phase boundaries of solvent polymeric ISE membranes have been studied thoroughly [3335]. The diffusion coefficients of relevant components have been determined as a function of the membrane composition [36-38]. Their knowledge has turned out to be very important because the lower limit of detection (LOD) of polymeric membrane ISEs is often directly influenced by the internal diffusion processes of membranes (see below).

\section{Lower LOD and selectivity coefficients}

In spite of the richness of the above-mentioned results, the real revolution in potentiometry was brought about by the extraordinary improvement in the lower LOD and selectivity behavior of ISEs. Until about 10 years ago, it was common knowledge that ISEs could not be used at concentrations below $10^{-6} \mathrm{M}$ and that the discrimination factors of interfering ions, the potentiometric selectivity coefficients, could not be better than $10^{-4}-10^{-5}$. In the meantime, there have already become available ISEs with lower LODs in the range $10^{-8}-10^{-11} \mathrm{M}$ (i.e. 
down to the low ppt range) for 12 ions, and many selectivity coefficients found to be < $10^{-10}$, sometimes even $<10^{-15}$ [39].

It should be noted that the definition of the lower LOD of ISEs (as defined by IUPAC [40]) does not agree with that of other methods (also by IUPAC [41]), so the range above should be further lowered by about two orders of magnitude (i.e. to ca. $10^{-10}-10^{-13} \mathrm{M}$ ), if potentiometry is compared with other analytical methods [39].

What could cause such a revolution? It is ironical that, for decades, one simple bias hindered the development of such high-performance ISEs. By convention, on their inner side, ISE membranes were in contact with a rather concentrated solution of the primary (analyte) ion. The discovery that their response characteristics may strongly depend on the composition of this solution was the starting point of the improvements [42,43]. It is now obvious that the flux of ions from the membrane to the sample brings about a limiting concentration of the primary ions near the sensing membrane, even if the bulk of the sample is further diluted [44]. Today, the response of ISEs in the presence of ion fluxes is well understood [45-47] and it is also clear that, although such ion-flux effects can be strongly reduced, they cannot be entirely eliminated. The numerous methods of decreasing these biasing effects are related to the adjustment of the inner solution [47], the reduction of ion diffusion in the membrane and/or its acceleration in water [48], and the compensation of ion fluxes by an external current [49]. As an example, the responses of two $\mathrm{Ca}^{2+}$-ISEs are compared in Fig. 1. One is based on a monolithic capillary and the other on a conventional poly(vinyl chloride) (PVC) membrane [50].

Within a short time after being developed, ISEs with highly improved lower LODs were shown to be applicable to the environmental monitoring of trace metals [51-53]. It is important to keep in mind that the different analytical techniques detect different forms of the species to be determined. While the response of an ISE depends on free ionic activities, voltammetric methods yield information on the concentration of chemically available (labile) analytes, whereas atomic spectrometric methods atomize the entire sample and do not distinguish between the different forms of the analyte.

Combination of different techniques is a straightforward way of speciation. The $\mathrm{pH}$ dependence of the response of a $\mathrm{Pb}^{2+}$-ISE to $10 \mathrm{ppb} \mathrm{Pb}^{2+}$ illustrates this in the left panel of Fig. 2. At $\mathrm{pH}$ $>4.0$, the increasing amount of carbonate successively reduces the activity of free $\mathrm{Pb}^{2+}$ (the dashed curve displays the calculated response to a total concentration of $4.14 \times 10^{-3} \mathrm{M}$ carbonate). The right panel of Fig. 2 shows the excellent agreement of the results obtained by potentiometry at $\mathrm{pH} 4.0$ and by inductively coupled plasma mass spectrometry (ICP-MS) [51]. The novel ISEs with much improved lower LODs have also been successfully applied in bio-uptake studies of $\mathrm{Pb}^{2+}$ and $\mathrm{Cd}^{2+}[54,55]$.

In contrast to other analytical techniques, potentiometric measurements do not consume the analytes, so they are especially attractive when low total amounts are to be measured. Recently, sub-femtomole LODs were reported for different cations (for an example, see Fig. 3) [56].

\section{Non-classical responses; use of ion fluxes}

Traditionally, it was assumed that, during potentiometric measurements, the composition of the ISE membrane remains unchanged and that the composition of the sample near the membrane is the same as in the bulk. A number of new non-classical concepts are related to systems in which these assumptions are not valid [57].

First, ISEs for polyions, such as heparin and protamine, must be mentioned. Due to the high charge numbers of up to 70 of these ions, the sensitivity (i.e. the response slope) of a traditional ISE would be extremely low. However, by relying on a non-equilibrium response [31], highly 
sensitive polyion sensors of clinical relevance have been successfully developed by Meyerhoff's group [58]. In another approach, enhanced sensitivities of the potentiometric measurement of metal ions were achieved by making use of strong ion fluxes [59]. The uptake of ions by the sensing membrane can also be used to improve the LOD in potentiometric titrations [60]. Electrodes with twice or thrice the Nernstian response can be obtained when the composition of the membrane changes with that of the sample [61,62]. Although the potentiometric response always depends on ion activities, total concentrations have been determined using polymeric membranes with relevant ion fluxes [63]. Finally, with membranes in which ion fluxes are strong, such as supported liquid membranes, novel calibration principles have become possible $[64,65]$. Concentration gradients across thin, supported liquid ISE membranes can be assessed by determining the direction of the potential drift upon altering the stirring rate on either side of the membrane. The disappearance of this drift indicates the absence of concentration gradients across the membrane and is used to determine the sample composition $[64,65]$.

\section{Solid contact}

In the conventional set-up, the back side of ISE membranes is in contact with an electrolyte in order to obtain stable potentials. Although ISEs with an internal solid contact, which allows a much simpler fabrication, have been known for more than 30 years [66], until recently, they have shown insufficient potential stability. Currently, intensive research is taking place in this area. An internal contact with conducting polymers $[67,68]$ seems to be especially promising. The improved lower LODs [69,70], the possible miniaturization of the sensors [71] and their simple construction [72] make these systems very attractive. Although some of their aspects are, at present, not yet fully understood, it seems that they represent the typical way of constructing the next ISE generation.

\section{Prospects}

For decades, plasticized PVC used to be the dominating membrane matrix. More recently, polyacrylates and polymethacrylates [73] have been investigated by various groups. Due to the much lower diffusion coefficients of the dissolved components [38], these matrices are especially attractive in controlling the ion fluxes in the membrane. They are likely to become the standard matrix of future miniaturized solid-contact ISEs.

Once an ISE membrane is characterized, the interference by ionic species can be fully predicted. Unfortunately, this is not the case with lipophilic compounds, which are often present in biological samples and can be extracted into the membrane [74]. Enhancing the biocompatibility of ISE membranes has, therefore, been an important research topic [75]. The recent development of fluorous phases as extremely lipophilic ISE membrane components might be a solution to this problem [76]. These emerging systems may become very important, especially for clinical potentiometric analyses.

At present, novel applications of miniaturized ISEs with very low LODs are being developed. Since such electrodes are especially attractive for low amounts of sample [56], potentiometric biosensing using nanoparticle labels might become an inexpensive alternative to optical detection [77].

Voltammetric investigations at the interface of two immiscible liquids as models of ISEs have a long tradition [78]. More recently, various, as yet unforeseen, possibilities of ion-transfer voltammetry with ionophore-based polymeric membranes have been emerging [79]. Such systems offer attractive alternatives to traditional potentiometry [80]. As an example, the responses of a pulsed amperometric sensor and a conventional ISE to the polycation protamine are compared in Fig. 4 [81]. 
This short summary of recent novel developments shows that the dynamic progress in the field of potentiometric sensors is more vivid than it was 25 years ago.

\section{Acknowledgements}

This work was financially supported by the Swiss National Science Foundation, an internal research grant of the ETH Zurich, and the National Institutes of Health (grant R01-EB02189). The author thanks D. Wegmann for careful reading of the manuscript.

\section{References}

1. Buck RP, Lindner E. Anal Chem 2001;73:88A.

2. Ross JW. Science (Washington, DC) 1967;156:1378.

3. Bloch R, Shatkay A, Saroff HA. Biophys J 1967;7:865.

4. Stefanac Z, Simon W. Microchem J 1967;12:125.

5. Pedersen CJ. J Am Chem Soc 1967;89:2495.

6. Dietrich B, Lehn JM, Sauvage JP. Tetrahedron Lett 1969;34:2885.

7. Bakker E, Bühlmann P, Pretsch E. Chem Rev 1997;97:3083. [PubMed: 11851486]

8. Bühlmann P, Pretsch E, Bakker E. Chem Rev 1998;98:1593. [PubMed: 11848943]

9. Thomas RC, Simon W, Oehme M. Nature 1975;258:754. [PubMed: 1207762]

10. Young CC. J Chem Educ 1997;74:177.

11. Ciani SM, Eisenman G, Szabo G. J Membr Biol 1969;1:1.

12. Morf, WE. The Principles of Ion-Selective Electrodes and of Membrane Transport. Elsevier; New York, USA: 1981.

13. Buck RP, Lindner E. Acc Chem Res 1998;31:257.

14. Pungor E. Pure Appl Chem 1992;64:503.

15. Bakker E, Bühlmann P, Pretsch E. Talanta 2004;63:3.

16. Bakker E, Pretsch E, Bühlmann P. Anal Chem 2000;72:1127. [PubMed: 10740849]

17. Bakker E, Meruva RK, Pretsch E, Meyerhoff ME. Anal Chem 1994;66:3021. [PubMed: 7978299]

18. Nägele M, Bakker E, Pretsch E. Anal Chem 1999;71:1041.

19. Bakker E, Pretsch E. Anal Chem 1998;70:295.

20. Ceresa A, Pretsch E. Anal Chim Acta 1999;395:41.

21. Mi Y, Bakker E. Anal Chem 1999;71:5279. [PubMed: 10596210]

22. Shultz MM, Stefanova OK, Mokrov SB, Mikhelson KN. Anal Chem 2002;74:510. [PubMed: $11838668]$

23. Bakker E, Willer M, Lerchi M, Seiler K, Pretsch E. Anal Chem 1994;66:516.

24. Bourgeois J-P, Echegoyen L, Fibbioli M, Pretsch E, Diederich F. Angew Chem Int Ed Engl 1998;37:2118.

25. van den Berg A, van der Waal PD, Skowronska-Ptasinska M, Sudhölter EJR, Reinhoudt DN, Bergveld P. Anal Chem 1987;58:2827.

26. Nägele M, Pretsch E. Mikrochim Acta 1995;121:269.

27. Gyurcsányi RE, Lindner E. Anal Chem 2002;74:4060. [PubMed: 12199575]

28. Schaller U, Bakker E, Spichiger UE, Pretsch E. Anal Chem 1994;66:391.

29. Amemiya S, Bühlmann P, Umezawa Y, Rusterholz B, Pretsch E. Anal Chem 2000;72:1618. [PubMed: 10763261]

30. Bakker E, Malinowska E, Schiller RD, Meyerhoff ME. Talanta 1994;41:881.

31. Fu B, Bakker E, Yun JH, Yang VC, Meyerhoff ME. Anal Chem 1994;66:2250. [PubMed: 8080104]

32. Steinle ED, Amemiya S, Bühlmann P, Meyerhoff ME. Anal Chem 2000;72:5766. [PubMed: 11128934]

33. Schneider B, Zwickl T, Federer B, Pretsch E, Lindner E. Anal Chem 1996;68:4342.

34. Lindner E, Zwickl T, Bakker E, Lan BTT, Tóth K, Pretsch E. Anal Chem 1998;70:1176.

35. Gyurcsányi RE, Lindner E. Anal Chem 2005;77:2132. [PubMed: 15801747] 
36. Püntener M, Fibbioli M, Bakker E, Pretsch E. Electroanalysis (NY) 2002;14:1329.

37. Long R, Bakker E. Anal Chim Acta 2004:91.

38. Heng LY, Tóth K, Hall EAH. Talanta 2004;63:73.

39. Bakker E, Pretsch E. Trends Anal Chem 2005;24:199.

40. Guilbault GG, Durst RA, Frant MS, Freiser H, Hansen EH, Light TS, Pungor E, Rechnitz G, Rice NM, Rohm TJ, Simon W, Thomas JDR. Pure Appl Chem 1976;48:127.

41. Currie LA. Pure Appl Chem 1995;67:1699.

42. Mathison S, Bakker E. Anal Chem 1998;70:303.

43. Sokalski T, Ceresa A, Zwickl T, Pretsch E. J Am Chem Soc 1997;119:11347.

44. Gyurcsányi RE, Pergel E, Nagy R, Kapui I, Lan BTT, Tóth K, Bitter I, Lindner E. Anal Chem 2001;73:2104. [PubMed: 11354497]

45. Sokalski T, Zwickl T, Bakker E, Pretsch E. Anal Chem 1999;71:1204.

46. Morf WE, Badertscher M, Zwickl T, de Rooij NF, Pretsch E. J Phys Chem B 1999;103:11346.

47. Ceresa A, Radu A, Peper S, Bakker E, Pretsch E. Anal Chem 2002;74:4027. [PubMed: 12199570]

48. Szigeti Z, Vigassy T, Bakker E, Pretsch E. Electroanalysis (NY) 2006;18:1254.

49. Lindner E, Gyurcsányi RE, Buck RP. Electroanalysis (NY) 1999;11:695.

50. Vigassy T, Huber CG, Wintringer R, Pretsch E. Anal Chem 2005;77:3966. [PubMed: 15987098]

51. Ceresa A, Bakker E, Hattendorf B, Günther D, Pretsch E. Anal Chem 2001;73:343. [PubMed: 11199988]

52. Szigeti Z, Bitter I, Tóth K, Latkoczy C, Fliegel DJ, Günther D, Pretsch E. Anal Chim Acta 2005;532:129.

53. Radu A, Peper S, Gonczy C, Runde W, Diamond D. Electroanalysis (NY) 2006;18:1379.

54. Slaveykova VI, Wilkinson KJ, Ceresa A, Pretsch E. Environ Sci Technol 2003;37:1114. [PubMed: 12680663]

55. Plaza S, Szigeti Z, Geisler M, Martinoia E, Pretsch E. Anal Biochem 2005;347:10. [PubMed: 16266684]

56. Malon A, Vigassy T, Bakker E, Pretsch E. J Am Chem Soc 2006;128:8154. [PubMed: 16787077]

57. Bakker E, Meyerhoff ME. Anal Chim Acta 2000;416:121.

58. Meyerhoff ME, Fu B, Bakker E, Yun JH, Yang VC. Anal Chem 1996;68:168A.

59. Vigassy T, Morf WE, Badertscher M, Ceresa A, de Rooij NF, Pretsch E. Sens Actuators 2001;B 76:477.

60. Peper S, Ceresa A, Bakker E, Pretsch E. Anal Chem 2001;73:3768. [PubMed: 11510846]

61. Amemiya S, Bühlmann P, Umezawa Y. Anal Chem 1998;70:445.

62. Bühlmann P, Umezawa Y. Electroanalysis (NY) 1999;11:687.

63. Ceresa A, Pretsch E, Bakker E. Anal Chem 2000;72:2050. [PubMed: 10815964]

64. Tompa K, Birbaum K, Malon A, Vigassy T, Bakker E, Pretsch E. Anal Chem 2005;77:7801. [PubMed: 16316191]

65. Malon A, Bakker E, Pretsch E. Anal Chem 2007;(79):632. [PubMed: 17222030]

66. Cattrall RW, Freiser H. Anal Chem 1971;43:1905.

67. Cadogan A, Gao Z, Lewenstam A, Ivaska A, Diamond D. Anal Chem 1992;64:2496.

68. Bobacka J. Electroanalysis (NY) 2006;18:7.

69. Michalska A, Dumanska J, Maksymiuk K. Anal Chem 2003;75:4964.

70. Sutter J, Lindner E, Gyurcsányi R, Pretsch E. Anal Bioanal Chem 2004;380:1. [PubMed: 15309369]

71. Sundfors L, Bereczki R, Bobacka J, Tóth K, Ivaska A, Gyurcsányi RE. Electroanalysis (NY) 2006;18:1372.

72. Chumbimuni-Torres KY, Rubinova N, Radu A, Kubota LT, Bakker E. Anal Chem 2006;78:1318. [PubMed: 16478128]

73. Heng LY, Hall EAH. Anal Chim Acta 1996;324:47.

74. Bühlmann P, Hayakawa M, Ohshiro T, Amemiya S, Umezawa Y. Anal Chem 2001;73:3199. [PubMed: 11476216] 
75. Gavalas VG, Berrocal MJ, Bachas LG. Anal Bioanal Chem 2006;384:65. [PubMed: 16132141]

76. Boswell P, Bühlmann P. J Am Chem Soc 2005;127:8958. [PubMed: 15969566]

77. Chumbimuni-Torres KY, Zong D, Rubinova N, Xiang Y, Pretsch E, Wang J, Bakker E. J Am Chem Soc 2006;128in press

78. Samec Z, Marecek V, Koryta J, Khalil MW. J Electroanal Chem 1977;83:393.

79. Shvarev A, Bakker E. Anal Chem 2003;75:4541. [PubMed: 14632062]

80. Makarychev-Mikhailov S, Shvarev A, Bakker E. J Am Chem Soc 2004;126:10548. [PubMed: 15327306]

81. Shvarev A, Bakker E. J Am Chem Soc 2003;125:11192. [PubMed: 16220929] 

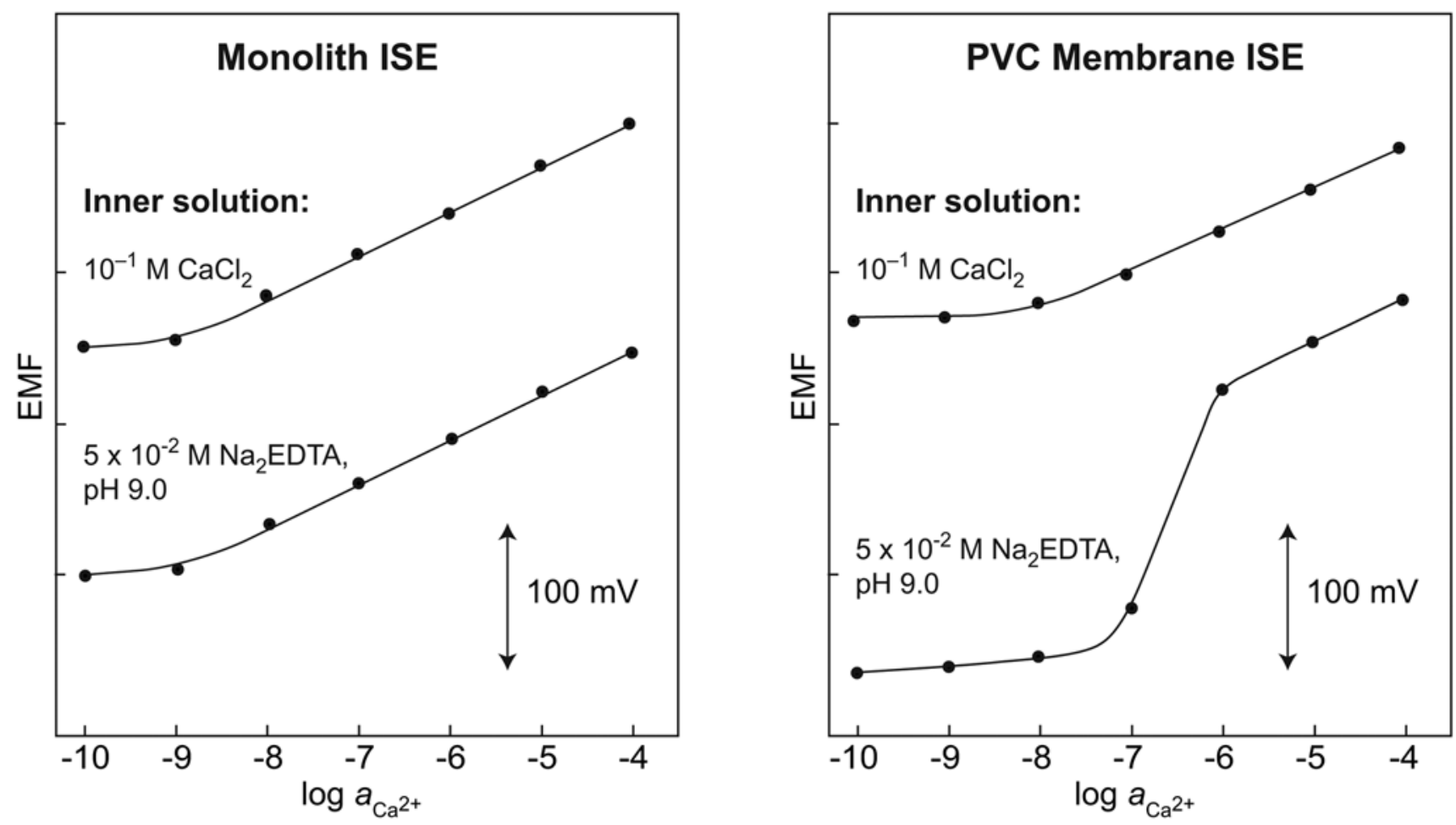

Figure 1.

Calibration curves for two types of a $\mathrm{Ca}^{2+}$-selective membrane electrode, each with two different inner solutions, as indicated. Left: ISE based on a monolithic capillary (200 $\mu \mathrm{m}$ i.d.) and a membrane solution without PVC [50]. Right: ISE with conventional plasticized PVC membrane (5 mm o.d., ca. $150 \mu \mathrm{m}$ thickness) [50]. The EMF responses were recorded in $\mathrm{CaCl}_{2}$ solutions at $\mathrm{pH} 6.2$ (successive dilutions) with $10^{-4} \mathrm{M} \mathrm{NaCl}$ as background electrolyte. With the conventional PVC membrane, because of ion fluxes from the membrane into the sample (inner solution $10^{-1} \mathrm{M} \mathrm{CaCl}_{2}$ ) or in the case of $5 \times 10^{-2} \mathrm{M} \mathrm{Na}_{2}$ EDTA ( $\mathrm{pH} 9.0$ ) from the sample into the membrane, LODs are less than optimal. With the monolith ISE, the composition of the inner solution has virtually no effect on the response. 

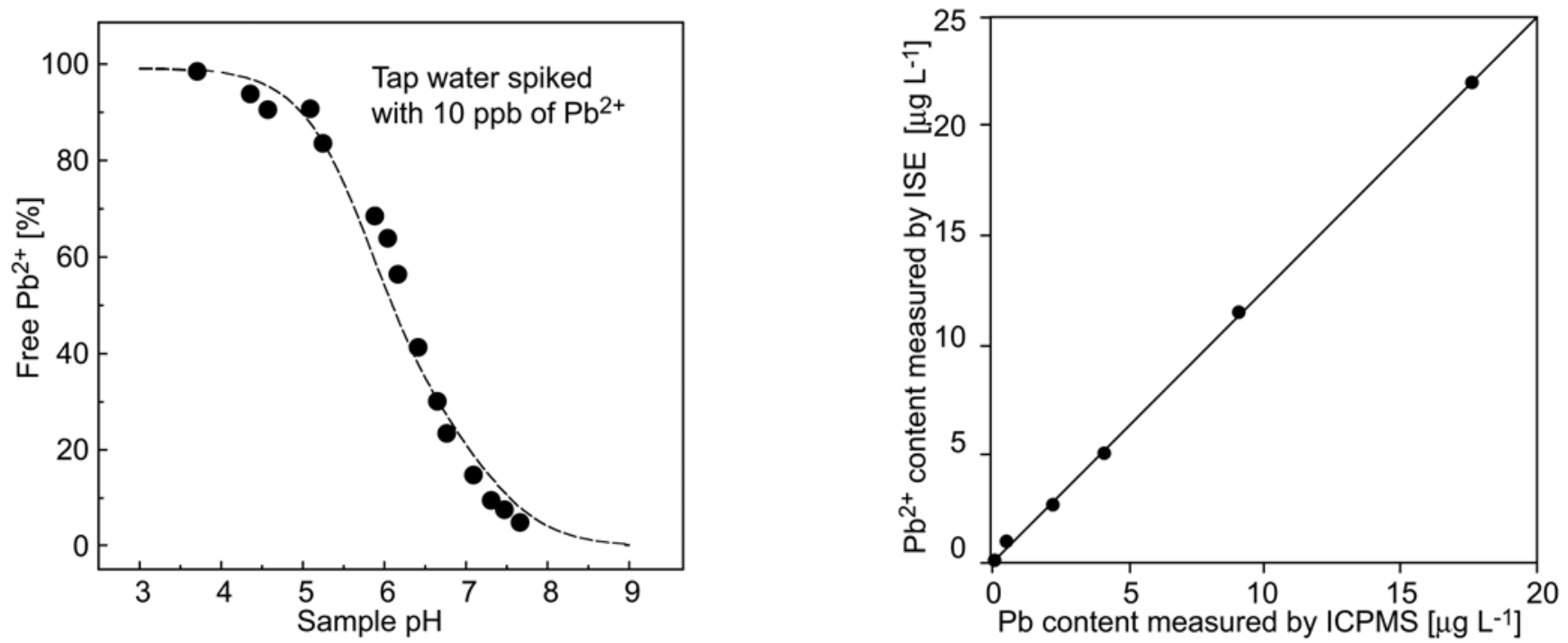

Figure 2.

Left: Speciation analysis of drinking water spiked with $10 \mathrm{ppb}$ of $\mathrm{Pb}^{2+}$. Data points for $\%$ of free $\mathrm{Pb}^{2+}$ as a function of the sample $\mathrm{pH}$. Dashed line: Calculated free $\mathrm{Pb}^{2+}$ activity for a total carbonate concentration of $4.14 \mathrm{mM}$ [51]. Right: Comparison of the values obtained by potentiometry at $\mathrm{pH} 4.0$ with ICP-MS measurements [51]. 

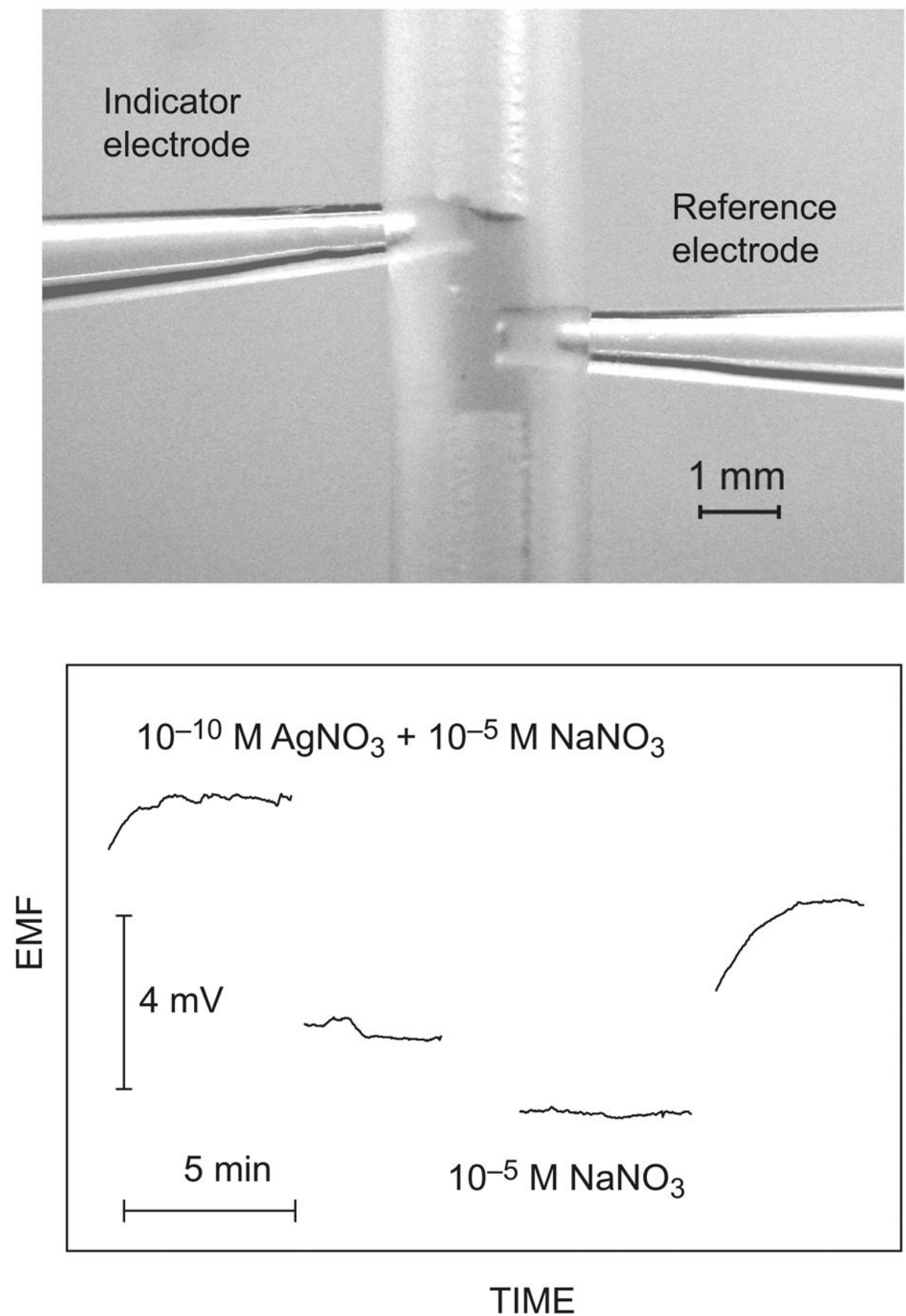

Figure 3.

Top: Detail of the 3- $\mu \mathrm{L}$ measuring cell. The $\mathrm{Ag}^{+}$-ISE (left, indicator electrode) and a $\mathrm{Na}^{+}-\mathrm{ISE}$ reference electrode (right) are inserted into a 1-mm i.d. silicone tube and put in contact with the aqueous sample plug $(3 \mu \mathrm{L})$. Bottom: Potentiometric detection of 300 attomol of $\mathrm{Ag}^{+}$ $\left(10^{-10} \mathrm{M}\right.$ in $\left.3 \mu \mathrm{L}\right)$ at a constant background of $10^{-6} \mathrm{M} \mathrm{NaNO}_{3}$ [56]. 

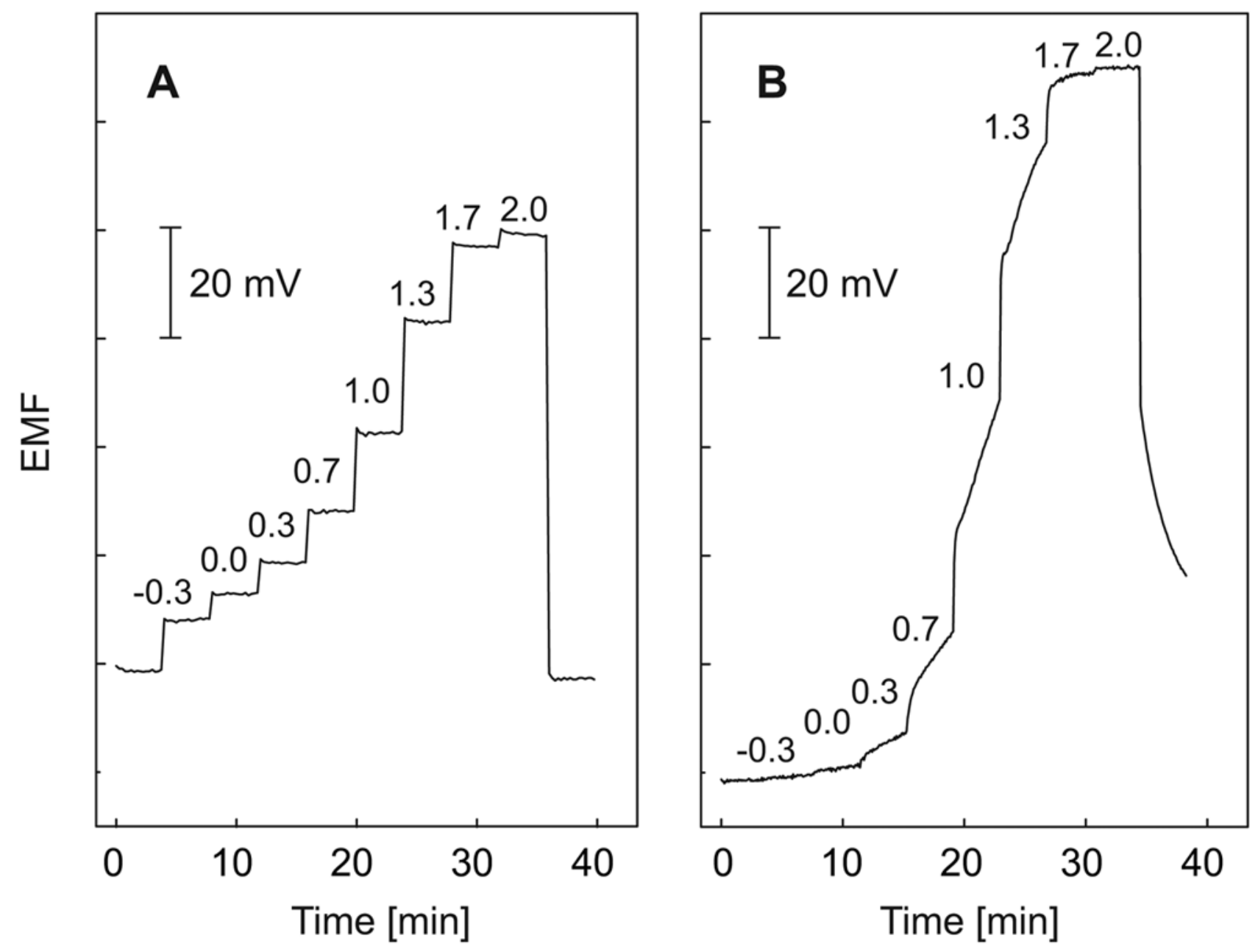

Figure 4.

Calibration curves for protamine in $0.1 \mathrm{M} \mathrm{NaCl}$. A: with pulsed galvanostatic technique: B: with a conventional protamine ISE. Logarithmic protamine concentrations $(\mathrm{mg} / \mathrm{L})$ are indicated on the traces (first and last samples are $0.1 \mathrm{M} \mathrm{NaCl}$ ) [81]. 